\title{
RISK FACTORS FOR PROSTATE CANCER PATIENTS AMONG GEZIRA STATE-CENTRAL OF SUDAN
}

\author{
F.A. HAMAD ${ }^{1}$ AND D.O. ABUIDRIS ${ }^{2}$ \\ ${ }^{l}$ Department of Biochemistry, Faculty of Applied Medical Sciences, \\ University of Gezira, Sudan. \\ ${ }^{2}$ Department of Oncology, National Cancer Institute, University of Gezira, Sudan.
}

fatimaabubaker@yahoo.com

\begin{abstract}
The aim of this study is to assess the risk factors for prostate cancer among Sudanese patients treated in National Cancer Institute (NCI), Gezira University, Wadmedani, Sudan. The study was performed on 268 prostate cancer patients, age ranging between 45-98 years. Similar number of 268 persons (age and sex matched) was used as control group. The study period was from May-2006 to December-2009. Data was collected from patients using a questionnaire which was filled in order to obtain information regarding: age, residence, tribe, education levels, occupation, marital status, stage of disease, family history and habits .The body mass index (BMI) was determined by anthropometrics measurements (weight and height). Prostate cancer is the commonest cancer among male patients treated in the NCI. The mean age of patients was 72.2 \pm 9.25 . Most of patients (73.9\%) were over 66-years. Family history is positive in $18(6.7 \%)$ of the patients. Rural inhabitants were $79.8 \%$ of all cases. The disease is equally distributed among different tribes. The illiteracy among cases is $39.1 \%$. The commonest occupation was farming $(60.1 \%)$. Majority $(90.7 \%)$ of the patients were married. Most cases (85.4\%) presented with stage III and IV. $73 \%$ of the patients had one or more of unhealthy habits (smoking, snuff and alcohol). the BMI was high in $6.9 \%$ of the patients. Risk factors for prostate cancer in the study area, which may appear to have a high significant effect, were: the age, education level, occupation, unhealthy habits and the BMI.
\end{abstract}

ABSTRAK: Tujuan kajian ini dijalankan ialah untuk menilai faktor-faktor risiko untuk kanser prostat di kalangan pesakit-pesakit yang dirawat di Institut Kanser Kebangsaan (NCI), Universiti Gezira, Wadmedani, Sudan. Kajian dijalankan pada 268 pesakit kanser prostat, berumur di antara 45-98 tahun. Jumlah bilangan pesakit yang sama iaitu seramai 268 orang (sama umur dan jantina) telah digunakan sebagai kumpulan kawalan. Tempoh kajian ialah pada Mei 2006 sehingga Disember 2009. Data diperolehi daripada pesakitpesakit dengan menggunakan boring soal selidik yang diisi untuk mendapatkan maklumat: umur, tempat tinggal, puak, taraf pendidikan, pekerjaan, status perkahwinan, peringkat penyakit, sejarah keluarga dan tabiat-tabiat. Indeks jisim badan (BMI) telah ditentukan melalui pengukuran antropometri (berat dan ketinggian). Kanser prostat ialah kanser yang paling banyak dihidapi pesakit-pesakit yang dirawat di NCI. Purata umur ialah 72.2 \pm 9.25 . Kebanyakan pesakit $(73.9 \%)$ berumurlebih 66 tahun. Sejarah keluarga ialah positif pada $18(6.7 \%)$ pesakit. Penduduk luar bandar ialah $79.8 \%$ daripada keseluruhan jumlah kes. Penyakit ini terbahagi sama rata di antara puak-puak. Kadar buta huruf di antara kes-kes ialah $39.1 \%$. Pekerjaan yang paling banyak ialah bertani (60.1\%). Majoriti (90.7\%) pesakit telah berkahwin. Kebanyakan kes-kes (85.4\%) menghidapi peringkat III dan IV penyakit. $73 \%$ daripada jumlah pesakit mempunyai satu atau lebih tabiat yang kurang sihat (merokok, menghidu, dan alkohol). 6.9\% pesakit mempunyai indeks jisim badan (BMI) yang tinggi. Faktor-faktor risiko untuk kanser prostat di dalam kawasan kajian yang menunjukkan kesan signifikan yang tinggi ialah: 
umur, taraf pendidikan, pekerjaan, tabiat-tabiat kurang sihat dan indeks jisim badan (BMI).

KEYWORDS: prostate cancer; body mass index; age; life-style; occupation; Sudan

\section{INTRODUCTION}

Worldwide, more than 670,000 men are diagnosed with prostate cancer every year, accounting for one in nine of all new cancers in males. Recent incidence rates are heavily influenced by the availability of serum prostate specific antigen (PSA) testing in the population and incidence varies far more than mortality.Around 306,369 cases are diagnosed each year in Europe. The lowest European rates are in southern and Eastern Europe, while the highest rates are found in Scandinavia and northern European States [1]. Prostate cancer is now the most commonly diagnosed cancer in men as well as the second leading cause of male cancer deaths and occurs in 1 out of 6 men [2].

The only fully established risk factors for prostate cancer are increasing age, AfricanAmerican ethnicity, and family history of the disease. Research has almost conclusively established a link for male hormones (androgens) in the causation of prostate cancer, but the effects of these hormones are not fully understood. Although lifestyle factors (including diet and exercise) have been conclusively established as prostate cancer risk or protective factors, there is some evidence that a diet high in animal fat may account for differences noted in the incidence between different countries. However obesity has a high prevalence in patients with prostate cancer [3]. Smoking and alcohol increased the risk of prostate cancer [4]. The "Socioeconomic Factors" correlating to prostate cancer are population density, education, and income level [5].

Farmers; certain occupations and industries with exposures to cadmium, herbicides, and fertilizers; and men with low occupational physical activity levels have elevated prostate cancer risk [6].

Prostate cancer incidence increases dramatically with increasing age. Although it is a very unusual disease in men younger than 50 years, rates increase exponentially thereafter [7]. Prostate cancer increases faster with age than any other major cancer and, with an aging population, the burden of illness from prostate cancer will probably continue to increase in the future [2]. Risk increases two to three times for men with a family history of prostate cancer in a first-degree relative. The risk appears to be higher if the relative is a brother rather than a father, suggesting that the disease is recessive or linked to the $\mathrm{X}$ chromosome [8]. Risk is also increased if the affected relative is young or if more than one relative is affected [9]. The risk of developing and dying from prostate cancer is dramatically higher among blacks, is of intermediate levels among whites, and is lowest among native Japanese [10-11]. Black American men have higher rates of prostate cancer than white American men [10]. Education is an important attribute guiding the selection of occupation. This, in turn, is a predictive factor for disposable income and many socioeconomic aspects of life, including residential and lifestyle factors. Health conscious behaviour, such as seeking and affordability of healthy food and participation in health promotional and screening programs, relates to education and socioeconomic factors [12]. The incidence of prostate cancer correlates with population density, education, and income level [2]. The risk for prostate cancer was shown to have a much higher incidence within certain occupation, such as farming, as well as amongst mechanics, newspaper workers, plumbers, and men in rubber manufacturing industries [2]. Significant excess risks were seen for agriculture-related industries, soap and perfume manufacture, and leather 
processing industries. Significantly elevated standardized incidence ratios were observed amongst leather workers, and white-collar occupations [13]. Several investigators have studied the history of men with prostate cancer in an effort to determine if sexual behaviour and/or fertility are related to the development of prostate cancer [2]. The men with prostate cancer were sexually active earlier and had more partners than the control group, but other evidence appears to indicate the opposite [14-16].

The cigarette smoking may be a risk factor for the development of prostate cancer. Cadmium is a trace mineral found in cigarette smoke and alkaline batteries. People working in the welding and electroplating occupations are exposed to high levels of cadmium. Cadmium exposure places an individual at greater risk for prostate cancer; cadmium increases the risk for prostate cancer by interacting with zinc. Zinc is a necessary trace element in multiple intracellular metabolic pathways, and the prostate contains high amounts of zinc [2].

The body mass index (BMI) was calculated as weight in kilograms divided by the square of height in meters [17]. The World Health Organization (WHO) says that overweight and obesity are the most important known avoidable causes of cancer after tobacco. The obese patients had higher grade cancer and showed a trend toward having a more advanced pathologic stage [18]. The relationship between body mass index (BMI) and prostate cancer risk may be complex because obesity is associated with various hormonal factors and because the influence of BMI may differ according to whether the cancers are hereditary or sporadic [19] .Obesity is associated with endocrine changes (e.g., increased estrogen and decreased testosterone in the blood) that have been implicated in the cause of prostate cancer [20]. Dietary Fat, previous ecologic studies have demonstrated a direct relationship between a country's prostate cancer-specific mortality rate and average total calories from fat consumed by the country's population [21-22]. The relationship between other dietary factors and prostate cancer is complex. The risk increased with increasing dietary fat, animal fat and saturated and monounsaturated fat intake while approximately half of studies found no association between them and prostate cancer risk [23-24].

The men with the highest intake of dairy products and calcium were more likely to develop prostate cancer than men with the lowest intake. The advanced prostate cancer was the highest versus lowest intake categories of dairy products and the highest versus lowest intake categories of calcium [26].

No definitive links between prostate cancer and viruses have been established. The men with prostate cancer had higher titres of herpes virus and cytomegalovirus than did the control group in this study. The relationship between the risk for developing prostate cancer and a history of sexually transmitted disease remains unclear but appears tenuous [2].Vasectomy may increase the risk for prostate cancer because of the observation that vasectomised men have higher levels of circulating testosterone. A study by Sidney et al has found positive correlation between the number of years since vasectomy and prostate cancer risk. The relative risk for prostate cancer increased over time, with men who had a vasectomy 20 or more years in the past being the most at risk. There for vasectomy appears to confer an increased risk for the development of prostate cancer [2]. The history of benign prostatic hyperplasia carried a relative risk. A higher death rate from prostate cancer in men with a history of benign prostatic hyperplasia; however, the reasons for these findings remain unclear [2]. 


\section{MATERIALS AND METHODS}

The study covers all the 268 prostate cancer patients treated in the NCI from May 2006 to December 2009. Another 268 matched and not known to have prostate cancer persons from the main hospital attendants or the community were also chosen to form the control group. Data was collected using a formal designed questionnaire.

\subsection{Questionnaire}

For each patient a questionnaire data form was filled, in order to obtain information regarding: age, residence, tribe, education level, occupation, marital status, habits and past medical history. Date of diagnosis, stage of cancer and present complaints were also recorded. All questionnaires forms were filled by the first author.

\subsection{Anthropometric Measurements}

Weight, height and body mass index were measured. All patients' height and weight were taken. Body mass index was obtained using weight over the square of height. Readings were taken to the nearest $0.1 \mathrm{~kg}$ and $0.1 \mathrm{~cm}$.

\subsection{Analysis}

Statistical analysis was done using SPSS Programmed under window (IBM) computer system. $\mathrm{P}$ value of $<0.05$ is considered significant.

\section{RESULTS}

Most of the study patients, 202 (75.3\%) were inhabitants of Gezira State. The cases came from Central and Northern regions tribes and its distribution is similar to its normal census distribution. Majority of the patients studied (85.4\%) were diagnosed with stage III and IV disease (Table 1).

Table 1: Characteristics for prostate cancer patients $(\mathrm{n}=536)$.

\begin{tabular}{lllll}
\hline & & $\begin{array}{l}\text { Prostate } \\
\text { cancer(n=268) }\end{array}$ & Control (n=268) & Frequency (\%) \\
\hline \multirow{2}{*}{ State } & Gezira & $202(75.3 \%)$ & $268(100 \%)$ & $470(87.7 \%)$ \\
& Sinar & $25.0(9.3 \%)$ & - & $25.0(4.7 \%)$ \\
& Al gadarf & $21.0(7.8 \%)$ & - & $21.0(3.9 \%)$ \\
& Kurdfan & $7.0(2.6 \%)$ & - & $6.0(1.3 \%)$ \\
Kasla & $6.0(2.2 \%)$ & - & $4.0(0.7 \%)$ \\
& Blue Nile & $4.0(1.4 \%)$ & - & $2.0(0.4 \%)$ \\
White Nile & $2.0(0.74 \%)$ & - & $1.0(0.2 \%)$ \\
Tribes & $1.0(0.37 \%)$ & - & $187(34.8 \%)$ \\
& Al Khartoum & & & $225(41.9 \%)$ \\
& Northern tribes & $97(36.1 \%)$ & $90(33.6 \%)$ & $106(19.8 \%)$ \\
& Middle tribes & $104(38.8 \%)$ & $121(45.2 \%)$ & - \\
& Western tribes & $57(21.2 \%)$ & $49(18.3 \%)$ & $7(1.30 \%)$ \\
& Eastern tribes & $10(3.7 \%)$ & $1(0.37 \%)$ & $195 \%)$ \\
Stage & - & - & $32(11.9 \%)$ \\
& Southern tribes & - & - & $5(1.9 \%)$ \\
& Others & $197(73.5 \%)$ & - & $3(1.1 \%)$ \\
& Stage IV & $32(11.9 \%)$ & - & $31(11.6 \%)$ \\
& Stage III & $5(1.9 \%)$ & - &
\end{tabular}


More than $73.9 \%$ of cases occur in men over 66 years, with the largest number being diagnosed in the age period between 66 - 76 years.

In this study, $18(6.7 \%)$ of the patients had positive family history. The majority of the patients were married, 243 (90.7\%). Among the study population $73 \%$ of cases had one or more of the unhealthy habits like smoking, snuff and/or alcohol consumption. Strong association between unhealthy habits and prostate cancer was significant $(\mathrm{P}<0.000)$. more than $26 \%$ of the patients were snuffers (dipped tobacco usually under lips), $30 \%$ of were smokers, and $16 \%$ of the prostate cancer patients were alcohol drinkers. Thirty nine percent of the patients were illiterate. $\chi^{2}$ test performed on this group indicates that there is a significantly high association between the education level and prostate cancer ( $\mathrm{P}<0.000)$. Furthermore, 20.5\% (55) of the patients were underweight with BMI $(<18.5)$, and $93(34.7 \%)$ of them were in normal weight with BMI (18.5-24.9), but 45 $(16.9 \%)$ of the patients had high BMI $(\geq 25) \cdot \chi^{2}$ test performed on this data indicates that BMI has significant effects on prostate cancer with value of $\mathrm{P}<0.000$ (Table 2).

Occupations with low physical activity like office workers, drivers and teachers etc, represent more than $15 \%$ of all patients. However $60 \%$ (161) of the patients were farmer.

$\chi^{2}$ test performed on this data indicates that being a farmer or have an occupation with low physical activity has significant effect on prostate cancer $(\mathrm{P}<0.000)$.

\section{DISCUSSION}

In this study, it was found that age is the strongest risk factor with a statistically high significant effect. Prostate cancer is largely a disease of older men and is rare below the age of 45 years. This goes with the statements by Kirby et. al. [27], and Parkin et. al. [28], they stated that prostate cancer incidence increases dramatically with increasing age. Although it is a very unusual disease in men younger than 50 years, rates increase exponentially thereafter.

The domination of Gezira state inhabitants could be explained by the area, which NCI drain. The effect of ethnicity was described by Boring et al, who studied the incidence of clinical prostate cancer among different ethnic groups. African American men were found to have the highest incidence of prostate cancer, and Asian and Native American men have the lowest incidence [29]. In this study we can't see effect of ethnicity probably because most of the study area population have similar origin.

The family history findings agree with Steinberg et al, who reported that approximately $15 \%$ of men with a diagnosis of prostate cancer will be found to have a first-degree male relative (e.g., brother, father) with prostate cancer, compared with approximately $8 \%$ of the U.S. population. Approximately $9 \%$ of all prostate cancers may result from heritable susceptibility genes [30].

There is no significant association between sexual activity and prostate cancer, this agreed with Kenneth et al, who said that Marriage is often assumed to be synonymous with increased sexual activity, and fertility is often measured by the number of children a man admits to having fathered. It remains unclear if sexual activity has any relationship to prostate cancer risk [2]. 
IIUM Engineering Journal, Vol. 12, No. 4, 2011: Special Issue on Biotechnology

Hamad and AbuIdris

Table 2: Risk factors for prostate cancer patients $(n=536)$.

\begin{tabular}{|c|c|c|c|c|}
\hline & & $\begin{array}{l}\text { Prostate cancer } \\
\quad(n=268)\end{array}$ & $\begin{array}{l}\text { Control } \\
(n=268)\end{array}$ & $x^{2}$ test \\
\hline \multirow[t]{2}{*}{ Age } & $\geq 45$ & $2(0.74 \%)$ & $1(0.37 \%)$ & \multirow[t]{2}{*}{ Sig $(0.000)$} \\
\hline & $\leq 46$ & $266(99.25 \%)$ & $267(99.6 \%)$ & \\
\hline \multirow[t]{2}{*}{ Family history } & Positive & $18(6.7 \%)$ & - & \multirow[t]{2}{*}{ Sig (0.000) } \\
\hline & Negative & $250(93.2 \%)$ & $268(100 \%)$ & \\
\hline \multirow[t]{4}{*}{ Marital status } & Married & $243(90.7 \%)$ & $263(98.2 \%)$ & \multirow[t]{4}{*}{ NS } \\
\hline & Single & $4(1.4 \%))$ & $2(0.75 \%)$ & \\
\hline & Widow & $20(7.5 \%)$ & $3(1.1 \%)$ & \\
\hline & Divorce & $1(0.37 \%)$ & - & \\
\hline \multirow[t]{2}{*}{ Residence } & Rural & $214(79.8 \%)$ & $174(65 \%)$ & \multirow[t]{2}{*}{$\mathrm{NS}$} \\
\hline & Urban & $54(20.1 \%)$ & $94(35 \%)$ & \\
\hline \multirow{4}{*}{$\begin{array}{l}\text { Unhealthy } \\
\text { habits }\end{array}$} & Smoking & $81(30.2 \%)$ & $53(19.8 \%)$ & \multirow[t]{4}{*}{ Sig $(0.000)$} \\
\hline & Alcohol & $43(16 \%)$ & $5(1.86 \%)$ & \\
\hline & Snuff & $72(26.8 \%)$ & $48(18 \%)$ & \\
\hline & No habits & $143(53.3 \%)$ & $185(69 \%)$ & \\
\hline \multirow{6}{*}{$\begin{array}{l}\text { Education } \\
\text { levels }\end{array}$} & Illiterate & $105(39.1 \%)$ & $27(10.0 \%)$ & \multirow[t]{6}{*}{$\operatorname{Sig}(0.000)$} \\
\hline & Kalwa & $68(25.4 \%)$ & $40(15 \%)$ & \\
\hline & Primary & $54(20.1 \%)$ & $111(41.1 \%)$ & \\
\hline & Secondary & $28(10.4 \%)$ & $53(19.8 \%)$ & \\
\hline & University & $11(4.1 \%)$ & $37(13.8 \%)$ & \\
\hline & Above university & $2(0.74 \%)$ & - & \\
\hline \multirow[t]{7}{*}{ BMI } & Underweight & $55(20.5 \%)$ & $26(9.7 \%)$ & \multirow[t]{7}{*}{ Sig (0.000) } \\
\hline & Normal weight & $93(34.7 \%)$ & $131(48.9 \%)$ & \\
\hline & Overweight & - & $29(10.8 \%)$ & \\
\hline & Pre-obese & $30(11.2 \%)$ & $88(32.8 \%)$ & \\
\hline & Obese glass I & $12(4.5 \%)$ & $31(11.6 \%)$ & \\
\hline & Obese glass II & $3(1.1 \%)$ & - & \\
\hline & Obese glass III & - & - & \\
\hline \multirow[t]{11}{*}{ Occupations } & Farmer & $161(60.0 \%)$ & $31(11.6 \%)$ & \multirow[t]{11}{*}{ Sig (0.000) } \\
\hline & Worker & $39(14.6 \%)$ & $93(34.7 \%)$ & \\
\hline & Office worker & $13(4.8 \%)$ & $37(13.8 \%)$ & \\
\hline & Driver & $18(6.7 \%)$ & $34(12.7 \%)$ & \\
\hline & Free job & $18(6.7 \%)$ & $20(7.5 \%)$ & \\
\hline & Teacher & $9(3.3 \%)$ & $30(11.2 \%)$ & \\
\hline & Mechanic & $3(1.1 \%)$ & $8(3.0 \%)$ & \\
\hline & Nurse & $3(1.1 \%)$ & $2(0.75 \%)$ & \\
\hline & Policeman & $2(0.75 \%)$ & $8(3.0 \%)$ & \\
\hline & Engineer & $1(0.37 \%)$ & $5(1.9 \%)$ & \\
\hline & Imam (mosque) & $1(0.37 \%)$ & - & \\
\hline
\end{tabular}

A number of studies have found that cigarette smoking may be a risk factor for the development of prostate cancer. Hsing and colleagues demonstrated relative risks of 1.8 and 2.1 for cigarette smoking and chewing tobacco, respectively [31]. Also Bagnardi et. al., found a significant increased risk for men drinking more than $50 \mathrm{~g} /$ day of alcohol, with a slightly higher risk for men consuming more than $100 \mathrm{~g} /$ day [32]. Probably this study agrees with what has been published on the relation between tobacco/ alcohol and prostate cancer. The significance of literacy in this study agrees with Baquet and colleagues from the National Cancer Institute, who investigated the incidence of prostate cancer with population density, education, and income level [33]. Also this fact supported by Kari 
Hemminki et. al., who reported that educational level, may influence the risk of cancer in many ways [12]. Marjaana, published in 2001 that more than 35 studies on prostate cancer risk, most of it conclude that there is no association between prostate cancer risk and obesity. Some report that obese men are at a higher risk than men of healthy weight, particularly for more aggressive tumors. One study found an increased risk among men with high waist-to-hip ratios, suggesting that abdomen fat may be a more appropriate measure of body size in relation to prostate cancer [34]. Majority of the patients $(79.8 \%)$ were from rural area. The later finding may only reflect the nature of this area where we find that most of inhabitants are living in rural area. The higher incidence of prostate cancer patients in agricultural communities reflects the effect of the problems that farmer suffer from, such as exposure to pesticides, engine exhausts, solvents, dust, animal fuels, and specific microbes, this agrees with reports from National Cancer Institute, USA [35]. On the other hand $14.6 \%$ of the prostate cancer patients were workers from different fields. Kristan et al. published that many studies found moderate support for risk due to the following occupations: electrical power workers, water transport workers, aircraft fabricators, metal product fabricators, structural metal erectors, and railway transport workers. The following substances exhibited moderately strong associations: metallic dust, liquid fuel combustion products, lubricating oils and greases, and polyaromatic hydrocarbons from coal [36].

\section{CONCLUSION}

The common potential risk factors, among study population, include: age, education level and positive family history. Other factors include history of tobacco and alcohol consumption, BMI, and occupation. These findings are similar to the published literature. The dietary risk is not clear in Sudanese prostate cancer patients, because the relationship between dietary factors and prostate cancer is complex. Further research is needed to confirm these findings and identify specific exposures related to excess risk in some occupations and industries, including exposure to a variety of chemicals, such as pesticides, herbicides, fertilisers, solvents engine exhaust gases and organic dust and biological agents.

\section{REFERENCES}

[1] J. Ferlay, P. Autier, M. Boniol, M. Heanue, M. Colombet, and P. Boyle. "Estimates of the cancer incidence and mortality in Europe". Ann. Oncol., Vol 18, no. 3, 581-92, 2007.

[2] K.J. Pienta and P.S. Esper. "Risk Factors for Prostate Cancer". Ann. Intern. Med., Vol 118, no. $10,793-803,1993$.

[3] E. Giovannucci, E.B. Rimm, Y. Liu, M. Leitzmann, K. Wu, M.J. Stampfer, and W.C. Willett. "Body mass index and risk of prostate cancer in U.S. health professionals". JNCI Journal of the National Cancer Institute, Vol. 95, no. 16, 1240-1244, 2003.

[4] H. Grönberg, S.D. Isaacs, and J.R. Smith. "Characteristics of prostate cancer in families potentially linked to the hereditary prostate cancer 1 (HPC1) locus". JAMA Vol. 278, no. 15, 1251-1255, 1997.

[5] C.R. Baquet, J.W. Horm, T. Gibbs, P. Greenwald. "Socioeconomic factors and cancer incidence among blacks and whites". J Natl Cancer Inst., Vol. 83, 551-557, 1991.

[6] S.S. Wagner, A.P. Chokkalingam, H.S.R. Malker, B.J. Stone, J.K. McLaughlin, and A.W. Hsing. "Occupation and Prostate Cancer Risk in Sweden". Journal of Occupational \& Environmental Medicine, Vol 42, no. 5, 517-525, 2000.

[7] Epidemiological aspects. In: Kirby RS, Christmas TJ, Brawer MK: Prostate Cancer. London, England: Mosby, 1996: pp 23-32. 
[8] Monroe, K., et al. Evidence of an X-linked or recessive genetic component to prostate cancer risk. Nat Med. Vol 1, 827-829, 1995.

[9] Elo, J.P. and T. Visakorpi. Molecular genetics of prostate cancer. Ann Med. Vol 33, no. 2, 130-141, 2001.

[10] Ries LAG, Eisner MP, Kosary CL, et al., eds.: SEER Cancer Statistics Review, 1975-2002. Bethesda, Md: National Cancer Institute; 2005. Also available online www.nci.gov.

[11] Bunker CH, Patrick AL, Konety BR, et al.: High prevalence of screening-detected prostate cancer among Afro-Caribbeans: the Tobago Prostate Cancer Survey. Cancer Epidemiol Biomarkers Prev 11 (8): 726-9, 2002.

[12] Kari Hemminki and Xinjun Li. Level of Education and the Risk of Cancer in Sweden. Cancer Epidemiology, Biomarkers \& Prevention; 2003;796 Vol. 12, 796-802.

[13] Sharma-Wagner, Sangeeta; Chokkalingam, Anand P., Malker, Hans S. R.; Stone, B. J. ; McLaughlin, Joseph K.; Hsing, Ann W. Occupation and Prostate Cancer Risk in Sweden. Journal of Occupational \& Environmental Medicine; 2000; 42(5):517-525.

[14] Honda GD, Bernstein L, Ross LK, Greenland S, Gerkins V, Henderson B.Vasectomy, cigarette smoking and age at first sexual intercourse as risk factors for prostate cancer in middle-aged men. Br J Cancer 1988; 57:326-31.

[15] Rotkin I. Studies in the epidemiology of prostate cancer: expanded sampling. Cancer Treat Rep 1977; 61:173-80.

[16] Ross R, Deapen D, Casagrande J, et al. A cohort study of mortality from cancer of the prostate in Catholic priests. Br J Cancer 1981; 43:233-5.

[17] Timothy J. Key, 2003. Body Mass Index, Serum Sex Hormones, and Breast Cancer Risk in Postmenopausal Women. JNCI Journal of the National Cancer Institute 95(16):1218-1226.

[18] Motamedinia P, Korets R, Spencer BA, Benson MC, McKiernan JM. Body Mass Index Trends and Role of Obesity in Predicting Outcome After Radical Prostatectomy.2008.

[19] Edward Giovannucci, Eric B. Rimm, Yan Liu, Michael Leitzmann, Kana Wu, Meir J. Stampfer, Walter C. Willett. Body Mass Index and Risk of Prostate Cancer in U.S. Health Professionals. JNCI Journal of the National Cancer Institute; 2003; 95(16):1240-1244.

[20] Andersson SO, Wolk A, Bergström R, Adami HO, Engholm G, Englund A, Nyrén O. Body size and prostate cancer: a 20-year follow-up study among 135006 Swedish construction workers. 1997; 5;89(5):385-9.

[21] Armstrong B, Doll R: Environmental factors and cancer incidence and mortality in different countries, with special reference to dietary practices. Int J Cancer; 1975; 15 (4): 617-31.

[22] Rose DP, Connolly JM: Dietary fat, fatty acids and prostate cancer. Lipids; 1992; 27 (10): 798-803. [PUBMED Abstract]

[23] Optenberg SA, Thompson IM, Friedrichs P, et al.: Race. treatment, and long-term survival from prostate cancer in an equal-access medical care delivery system. JAMA; 1995; 274 (20): 1599-605.

[24] Wang Y, Corr JG, Thaler HT, et al. Decreased growth of established human prostate LNCaP tumors in nude mice fed a low-fat diet. J Natl Cancer Inst; 1995; 87 (19): 1456-62. [PUBMED Abstract]

[25] Bairati I, Meyer F, Fradet Y, et al.: Dietary fat and advanced prostate cancer. J Urol; 1998; 159 (4): 1271-5.

[26] Gao X, LaValley MP, Tucker KL. Prospective studies of dairy product and calcium intakes and prostate cancer risk: a meta-analysis. J Natl Cancer Inst; 2005; 97 (23): 1768-77. [PUBMED Abstract]

[27] Kirby RS, Christmas TJ, Brawer MK: Prostate Cancer. London, England: Mosby. Epidemiological aspects; 1996; 23-32.

[28] Parkin, D.M., et al. Cancer Incidence in Five Continents Volume VIII. IARC Scientific Publications. 2002; ed. Vol. 155. Lyon, France

[29] Boring CC, Squires TS, Tong T. Cancer statistics. Cancer; 1992; 42:19-39.

[30] Steinberg GD, Carter BS, Beaty TH, et al. Family history and the risk of prostate cancer. Prostate ; 1990; 17 (4): 337-47. 
[31] Hsing AW, McLaughlin JK, Schuman LM, Bjelke E, Gridley G, Wacholder S, et al. Diet, tobacco use, and fatal prostate cancer: results from the Lutheran Brotherhood Cohort Study. Cancer Res; 1990; 50:6836-40.

[32] Bagnardi, V., et al., A meta-analysis of alcohol drinking and cancer risk. Br J Cancer; 2001; 85(11): 1700-5.

[33] Baquet CR, Horm JW, Gibbs T, Greenwald P. Socioeconomic factors and cancer incidence among blacks and whites. J Natl Cancer Inst; 1991; 83: 551-7.

[34] Marjaana Lahti-Koski . Body mass index and obesity among adults in Finland. Publication of the National Public Health Institute; 2001: 51.

[35] National cancer Institute .U.S.National Institutes of Health. Prostate Cancer Prevention. Risk Factors for Prostate Cancer Development.WWW.cancer.gov.

[36] Kristan J. Aronson', Jack Siemiatycki, Ronald Dewar and Michel Gérin. Occupational Risk Factors for Prostate Cancer: Results from a Case-Control Study in Montréal, Québec, Canada. American Journal of Epidemiology; 1996; Vol. 143(4): 363-373. 